\title{
Global Increase in the Consumption of Lignocellulosic Biomass as Energy Source: Necessity for Sustained Optimisation of Agroforestry Technologies
}

\author{
Andrew Agbontalor Erakhrumen \\ Department of Forest Resources Management, University of Ibadan, Ibadan 200005, Nigeria \\ Correspondence should be addressed to Andrew Agbontalor Erakhrumen, erakhrumen@yahoo.com
}

Received 12 July 2011; Accepted 11 September 2011

Academic Editors: B. Chen and K. Kaygusuz

Copyright ( $) 2011$ Andrew Agbontalor Erakhrumen. This is an open access article distributed under the Creative Commons Attribution License, which permits unrestricted use, distribution, and reproduction in any medium, provided the original work is properly cited.

\begin{abstract}
Wood and other nonwood lignocellulosic materials are renewable natural resources useful for different applications based on end users' preference. Their use for generating energy, an application that has not been outmoded, has been noted to be increasing worldwide owing to multifarious reasons. Therefore, there has been the need for studies with results targeted at sustainable ways by which they can be sourced for this and other purposes, as this source of energy is currently still relevant particularly in the developing world. Agroforestry techniques that are based on realisable concepts acceptable to stakeholders have been suggested for this purpose. These age-long techniques are adopted for different purposes with incorporated components partly dependent on native intelligence, indigenous/traditional knowledge, and/or users' perspectives and expected outputs. Since wood and other lignocellulosic biomass can be obtained using these production techniques, optimising their potentials in this regard will be beneficial. This paper was therefore focused on the increasing trend in global wood fuel consumption and studies aimed at contributing to improvement of agroforestry systems as sustainable sources of wood fuel, a renewable source of energy.
\end{abstract}

\section{Introduction}

There is no gainsaying that the level and rate of development of any society is dependent on energy generation and consumption [1]. Fire, for instance, has been essential to civilisations for millennia, providing heat in the cold, light in the dark, and warm food. So fundamental is fire that most ancient societies have a myth relating to its "discovery", and since it was harnessed, biomass in the form of wood [2], nonwood lignocellulosic and nonlignocellulosic materials have been the primary fuel for it [1]. The situation does not appear to have changed in many parts of the world particularly those geographical locations termed developing countries [1,3-6].

This source of energy is so important in these areas that the intensity of demand and utilisation have continued to increase with trends that appear not to have the possibility of reversing in the foreseeable future [1, 3, 4, 6-12]. Even the areas termed developed countries that depend on fossil fuels, such as coal and petroleum, are gradually increasing biomass energy in their energy mix with renewed possibilities of future increases based on informed projections $[8,9]$, most of which is expected to be likely sourced from the developing countries $[1,4,13]$. The challenge is finding the sustainable combination of land use practices that still produces fuelwood while at the same time providing food crops and other environmental services [14].

There is, therefore, the need to be acquainted with information in this regard, most especially on sustainable strategies that can be adopted in contributing to the efforts aimed at preventing likely future "energy crisis" as a result of wood fuel shortage both at the local and global scales, even if this perceived "crisis" did not come to pass in the past, perhaps because firewood that were collected and traded were considered sustainable [2, 15], although, there were reports of fuelwood scarcity in some areas during the period [16] with charcoal production noted to be a possible contributor to forest degradation and destruction in some areas [17]. 


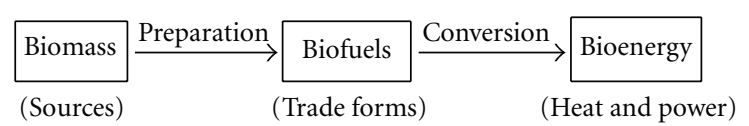

Figure 1: Flow diagram for bioenergy production.

Currently, information that will contribute to future sustainable wood fuel production is important, particularly for charcoal that has been noted to have a greater environmental cost than firewood collection (e.g., see Figure 3). This is because all the indices that led to the past predictions of future "energy crisis" in the 1970s and 1980s are still available and are likely to be aggravated by the present and future increases in the use of biomass energy in the developed countries. This might also be compounded by the unpredictability in the socioeconomic, political, interplay between these and other factors in the so-called developing countries.

One of such strategies that information is needed on is the development and application of agroforestry techniques that are locally devised and accepted based on native intelligence, indigenous/traditional knowledge, and/or users' perspectives of its components including their expected outputs $[4,6,10,11,18]$. This is particularly pertinent owing to recent observations that most firewood does not come from the forests but from trees in lots and woodlands outside of forests [2,15] such as agroforestry plots [19]. This paper is therefore aimed at highlighting the importance of supporting the development of agroforestry systems that are compatible with local realities as a sustainable source of wood for fuel.

\section{Current Trend in Global Consumption of Wood Fuel}

Renewable energy accounted for about $13.3 \%$ of the world's total primary energy [8], and it is believed that it will play an increasingly important role in energy supplies in both developing and developed societies in the future. Biofuels amounted to almost $80 \%$ of the total renewable energy supplying more energy than nuclear sources, and about four times as much as hydropower, wind, solar, and geothermal energy combined. About $75 \%$ of biofuels are derived from wood fuel (fuelwood, charcoal, and black liquor) [3]. The conceptual view of biomass energy in this paper is based on Food and Agriculture Organization (FAO) of the United Nations' Unified Bioenergy Terminology [20] as shown in Figure 1. It succinctly describes the process flow of bioenergy production from biomass to bioenergy.

Wood fuel refers to all types of biofuels derived directly and indirectly from trees and shrubs grown on forest and nonforest lands, from silvicultural activities, harvesting and logging, as well as industrial by-products [21]. It also simply refers to any energy source that comes from woody biomass covering a range of fuels, including fuelwood (sometimes used synonymously with firewood), charcoal, industrial fuelwood, wood pellets, biogas, cellulosic ethanol, and other advanced forms of bioenergy [2] that can be used for industrial, commercial, and domestic energy production obtained

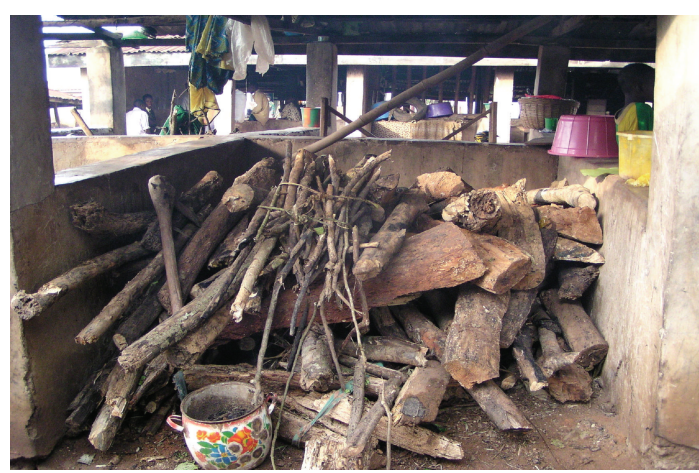

FIGURE 2: Firewood stored for later use.

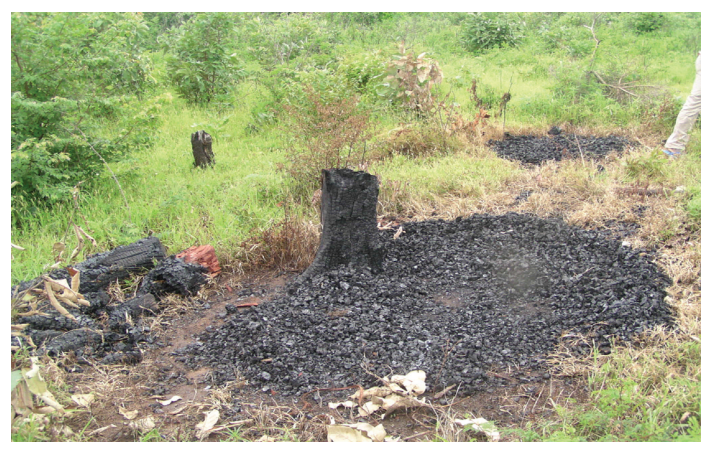

Figure 3: Remnants of charcoal in its production site.

through different biomass energy conversion routes with documented continuous modifications and development [1].

Wood fuel in the context of this discussion will be limited to fuelwood and charcoal owing to the fact that they are the mostly used types of wood fuel in developing countries through direct combustion in unprocessed form. Fuelwood, or firewood, consists of any unprocessed woody biomass used to fuel a small fire, most often for cooking or warmth while charcoal is a type of wood fuel made from burning wood in a very low- or no-oxygen environment $[1,2]$ through a process termed pyrolysis giving a mixture of other products such as complex and highly variable fuel gases and liquid. The appliances employed in burning fuelwood and charcoal range from the three-stone fire (see Figure 4), improved wood stove, charcoal stove with ceramic liner to sophisticated charcoal burning stove, among others [1]. Figure 2 shows pieces of firewood stored for later use while Figure 3 shows remnants of charcoal in its production site.

It was earlier estimated by Broadhead et al. [22] that global production of wood fuel will increase moderately from 1,885 million $\mathrm{m}^{3}$ in 2000 to 1,921 million $\mathrm{m}^{3}$ in 2010 and 1,954 million $\mathrm{m}^{3}$ in 2020 out of which it was also estimated, based on Hofstad et al. [17], that the tropics will consume about 1,400 million $\mathrm{m}^{3}$ of fuelwood each year, while around 40 million metric tons of charcoal will be produced with global charcoal supply in tropical countries being between a quarter and a half of the firewood supply based on a wood-to-charcoal conversion rate of between 8 
TABLE 1: Estimated future world demand for wood fuel up to the year 2040 .

\begin{tabular}{lcccc}
\hline Projected year & 2010 & 2020 & 2030 & 2040 \\
\hline Fuelwood total $\left(10^{9} \mathrm{~m}^{3}\right)$ & 1.9 & 1.7 & 1.8 & 1.9 \\
Domestic and commercial & 1.9 & 1.5 & 1.5 & 1.4 \\
Industrial bioenergy & 0 & 0.2 & 0.3 & 0.5 \\
\hline
\end{tabular}

Source: ITTO [23].

and 17. Recent estimates showed that consumption of wood fuel increased worldwide. For instance, between 2004 and 2006 alone, global consumption increased by $6 \%$ [14], an increasing trend that has been predicted to continue in this manner in the foreseeable future [8] as earlier noted. Table 1 shows the estimated future world demand for wood fuel up to the year 2040.

Presently, the bulk of energy needed by the countries of the developed world is obtained from fossil fuels; however, there are plans to increase the use of biofuel as an alternative source of energy as experienced in some countries like those of Organization for Economic Cooperation and Development such as Austria, Finland, Germany, and Sweden, where biomass, particularly wood, is increasingly being used for the production of energy, most especially electricity [8], heat, and power, used in forms which are considered to be more convenient. Earlier, estimates showed that wood energy accounts for more than 16 percent of total energy supply in Sweden and Finland, and 12 to 18 percent in some Central and East European countries [24] and as at present in many of these developed economies governments or utilities are now offering significant incentives (also known as subsidies) for investment in biomass energy [14].

Part of the reasons why biomass energy currently attracts attention is its renewability, potentials for decentralised production, and, more importantly, its carbon neutrality and hence its role concerning climate change mitigation [21]. However, the prospects of sourcing wood fuel from the developing countries to supply the developed countries in the future may encounter challenges in terms of feasibility or may even become a challenge to sustainable supply of wood fuel for local consumption, owing to the fact that almost all the wood fuel generated in this part of the world is presently consumed locally, a trend that will not likely change soon partly because wood fuel sourcing and consumption is central to domestic and commercial cooking and heating including sustenance of livelihood in these areas [4], for example, Figure 4 shows a woman cooking with firewood.

Apart from the projected future increase in wood fuel consumption in developing and developed countries, it is important to also note that some countries that are termed emerging economies like Brazil, China, India, and South Africa, among others, are likely to also increase their wood fuel consumption in the future thereby increasing the pressure on the available resources for this purpose. Nevertheless, in both developed and developing economies the property rights assigned to fuelwood are often very poor, the products of fuel wood is not seen as economically significant and there

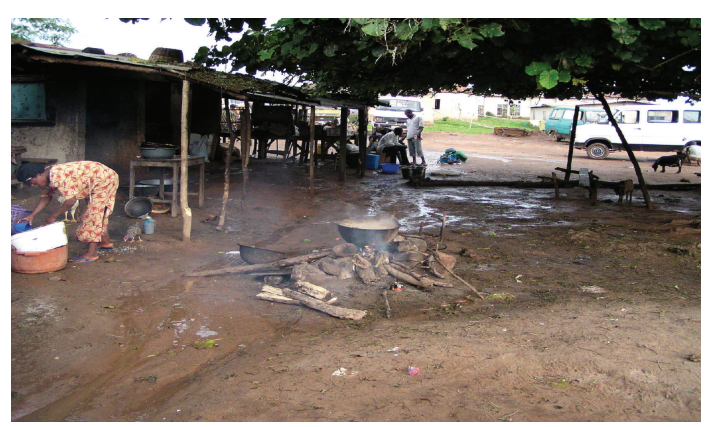

Figure 4: A woman cooking with firewood.

are presently no clear target for production that are linked to sustainability [14].

For instance, Tables 2, 3, and 4 showed that more than 99\% of the total wood fuel production in Africa, Asia, Latin America, and the Caribbean were consumed locally most of which were put to use at household/domestic level [25] in the rural areas [9], the periurban and urban areas [4]. It was also noted that the developing countries in Africa, Asia, Latin America, and the Caribbean collectively contributed more than $88 \%$ to the total world's wood fuel production while they also collectively consumed more than $88 \%$ of the world's total wood fuel consumption (Table 5). The data presented in the Tables were for the year 2004, a trend that has not significantly changed presently. Therefore, there is an increased necessity for more efforts toward sustainable means by which wood can be produced for generating energy.

This is imperative because there presently appear not to be a reliable alternative to this source of energy in the developing countries most especially in the rural areas [1]. It is noteworthy that the designations "developed" and "developing" are intended for convenience and do not necessarily express a judgement about the stage reached by a particular country or area in the development process [26]. This explanation should also suffice for defining "urban" or "rural" areas as division between them is often based on the assumption that the physical distinction between the two is self-explanatory and uncontroversial [6].

Nevertheless, developing country is a term generally used to describe a nation with a low level of material well-being. Most of the countries termed "developing countries" are located in Africa, Asia, Latin America, and the Caribbean. Thus, issues concerning sustainable wood fuel production is important in these countries, most especially those in SubSaharan Africa, where an average $52 \%$ of people live on less than US\$1 per day, and urban poverty is increasingly severe with about $43 \%$ of urban dwellers living below the poverty line of US\$47 per month per capita [27].

Issues concerning wood fuel are important in the rural areas, where most of the world population resides especially those in the developing world, where people living below poverty line are concentrated [28]. In Sub-Saharan Africa, there has been increase in people living in extreme poverty with growing population [29]. High dependence 
TABLe 2: Africa's production, trade, and consumption of wood fuel in 2004.

\begin{tabular}{|c|c|c|c|c|}
\hline \multirow[t]{2}{*}{ Region } & \multicolumn{4}{|c|}{$\begin{array}{l}\text { Total wood fuel volume } \\
\qquad\left(1000 \mathrm{~m}^{3}\right)\end{array}$} \\
\hline & Production & Imports & Exports & Consumption \\
\hline Central Africa & 103673 & 0 & 0 & 103673 \\
\hline East Africa & 194818 & 0 & 2 & 194816 \\
\hline Northern Africa & 46371 & 0 & 0 & 46371 \\
\hline Southern Africa & 55908 & 0 & 0 & 55908 \\
\hline West Africa & 145292 & 0 & 1 & 145291 \\
\hline Africa's total & 546062 & 1 & 4 & 546059 \\
\hline
\end{tabular}

Source: adapted from FAO [8].

TABLE 3: Asia's production, trade, and consumption of wood fuel in 2004.

\begin{tabular}{|c|c|c|c|c|}
\hline \multirow[t]{2}{*}{ Region } & \multicolumn{4}{|c|}{$\begin{array}{l}\text { Total wood fuel volume } \\
\qquad\left(1000 \mathrm{~m}^{3}\right)\end{array}$} \\
\hline & Production & Imports & Exports & Consumption \\
\hline Central Asia & 2146 & 5 & 2 & 2148 \\
\hline East Asia & 199545 & 8 & 6 & 199547 \\
\hline South Asia & 379960 & 0 & 0 & 379960 \\
\hline Southeast Asia & 186874 & 3 & 2 & 186875 \\
\hline Western Asia & 6123 & 301 & 1 & 6422 \\
\hline Asia's total & 774647 & 317 & 11 & 774953 \\
\hline
\end{tabular}

Source: adapted from FAO [8].

on traditional biomass as a source of energy and limited access to commercial and modern fuels is opined to be a manifestation of poverty [30]. It is however also necessary to note that poverty is multidimensional in nature with different meaning to different people.

For instance, poverty was defined by World Bank [31] as a pronounced deprivation in well-being, and comprises many dimensions. It includes low incomes and the inability to acquire the basic goods and services necessary for survival with dignity. Poverty also encompasses low levels of health and education, poor access to clean water and sanitation, inadequate physical security, lack of voice, and insufficient capacity and opportunity to better one's life.

While the United Nations fundamentally defined poverty as a denial of choices and opportunities, a violation of human dignity. It means lack of basic capacity to participate effectively in society. It means not having enough to feed and clothe a family, not having a school to attend or clinic to go to for medical facilities, not having the land on which to grow one's food or a job to earn one's living, not having access to credit. It means insecurity, powerlessness and exclusion of individuals, households, and communities. It means susceptibility to violence, and it often implies living in marginal or fragile environments, without access to clean water or sanitation.

Irrespective of the different definitions and opinions, poverty in its different dimensions should be a cause for reinforced concern, particularly in Sub-Sahara Africa, where sustainable development still appears to be elusive. The linkages between renewable natural resources and sustainable development in this region cannot be over emphasised.
Therefore, improper management of renewable natural resources, continuous intense unsustainable use of, and poor research and education concerning them will be counterproductive to achieving the much sought after sustainable development $[5,32]$. Wood energy can help promote development, especially in rural areas where the most investment is needed and the generation of employment is the most difficult [33].

It was observed that investments in biomass energy improve local economy [34] by adding value especially in terms of the potential for increasing employment opportunities, enhancing energy security, generating income through job creation and the development of a strong export industry, as well as the environmental benefit. For example, Minnesota's Department of Energy and Economic Development noted that $\$ 1$ spent on petroleum energy generates 34 cents of additional economic activity, while $\$ 1$ spent on biomass generates an additional $\$ 1.50$ of local economic activity. Thus, energy and energy systems have a central role in social and economic development and human welfare at all scales, from household and community to regional and national $[1,3,35,36]$.

\section{Agroforestry as a Means of Producing Renewable Natural Resources}

Agroforestry is a collective name for land-use systems and technologies where woody perennials (trees, shrubs, palms, etc.), bamboos, among others, are deliberately used on the same land management unit as agricultural crops and/or animals, in some form of spatial arrangement or temporal 
TABLE 4: Latin America and the Caribbean's production, trade, and consumption of wood fuel in 2004.

\begin{tabular}{lcccc}
\hline Region & & $\begin{array}{c}\text { Total wood fuel volume } \\
\left(1000 \mathrm{~m}^{3}\right)\end{array}$ & Exports & Consumption \\
& Production & 4977 & 0 & 4980 \\
Caribbean & 39473 & 0 & 0 & 39473 \\
Central America & 192153 & 0 & 0 & 192153 \\
South America & 236602 & 4 & 1 & 236605 \\
\hline Latin America and the Caribbean's total & & & 0 \\
\hline
\end{tabular}

Source: adapted from FAO [8].

TABLe 5: Comparison between the world and developing countries' 2004 total production, trade, and consumption of wood fuel.

\begin{tabular}{lcccc}
\hline Region & & \multicolumn{2}{c}{ Total wood fuel volume } \\
& Production & Imports & Exports & Consumption \\
& 546062 & 1 & 4 & 546059 \\
Africa & 774647 & 317 & 11 & 774953 \\
Asia & 236602 & 4 & 1 & 236605 \\
Latin America and the Caribbean & 1557311 & 322 & 3911 & 1557617 \\
Developing Countries' total & 1766925 & 3221 & 0.41 & 1766278 \\
World's total & 88.14 & 10 & 88.19 \\
\hline \% of World's total & & & 19 \\
\hline
\end{tabular}

Source: adapted from FAO [8].

sequence [37]. These production systems and technologies, although an age-long worldwide traditional practices, are currently being scientifically developed and continuously modified in many parts of the world, thereby receiving more global attention and scientific recognition and attention [18].

These methods of renewable natural resources production have been highly adjudged to be one of the solutions to the problems associated with availability of productive land for agriculture and forestry activities $[18,38]$, owing to their ability to combine agronomic crops and/or livestock and other types of animals with woody perennials on the same land management unit either simultaneously or sequentially in a deliberate manner [18]. These systems exist in various forms depending on localities, environments, plant and animal species, and their arrangement, management, and their socioeconomic functioning, among other factors.

Nair [39] briefly characterised agroforestry as follows: (a) agricultural systems (combining trees and agricultural crops), (b) silvopastoral (combining trees + pasture and/or animals), and (c) agrosilvopastoral systems (combining trees + crops + pasture/animals). Nevertheless, agroforestry is an infinitely elastic system of renewable natural resources production into which other different production systems can be incorporated with their adoption depending on many factors owing to multiple products derivable from agroforestry practices.

One of the major products deliverable from agroforestry is wood [40] that has applications for various purposes. These applications are influenced by so many factors that are dependent on resource producers, consumers/end users, and other stakeholders. The use of wood for fuel is one of the major applications it is put to in many rural areas of the developing countries. Thus, agroforestry practices as well as deliverables arising from its adoption have been identified as one of the possible solutions to the problems of wood fuel scarcity in some areas [41].

It has been observed that the large quantity of fuelwood required for their various activities can be sustained if farmers produce their own fuelwood rather than rely on natural vegetation [42] or established forest plantations that might be officially/legally inaccessible to rural populace even as it has been noted that firewood collection and trade is considered sustainable, for example, in most part of SubSaharan Africa [15]. Thus, on farm fuelwood production can become a profitable venture for small-scale farmers [15, 43]. Apart from this, establishing fuelwood plantations/woodlots may be more involving in that it requires a separate piece of land and is more expensive in terms of labour cost [44].

However, it is not only enough to recommend the combination of fuelwood with other components of renewable natural resources production methods, such as agroforestry schemes, but it is also very important to be acquainted with information relating to factors that influence or determine choice of individual components for incorporation into and sustenance in these schemes. This is because lack of these information and/or enquiry for them resulted in predominantly designing agroforestry technologies using external perspectives thereby leading to failures of many of these technologies or their rejection by farmers and other producers in the past $[4,11,18,45,46]$.

Recent studies have been able to show that series of factors, among which are socioeconomic, cultural, political, and so on, are responsible for components incorporation into and sustenance in agroforestry. For instance, Erakhrumen and Ogunsanwo [47] and Ogunsanwo and Erakhrumen [48] demonstrated the influence of gender on fuelwood sourcing 
and income generation in south-western part of Nigeria. It was noted that more women and children engaged in fuelwood sourcing and marketing in this study area as also observed in similar other studies $[49,50]$, perhaps, among other reasons, because ownership, access to, and use of these agroforestry plots are almost always influenced by gender division and sociocultural setting of communities.

The reasons for this are multifaceted but the main issue to be pointed out here is that when policies regarding agroforestry technologies are to be developed and subsequently implemented issues concerning gender should be an important factor for consideration. It is well known that most of the inhabitants of the developing countries that are living below poverty line are women and children $[47,51]$. Therefore, forest- and agroforestry-based income and employment opportunities are particularly important to this category of people because of the ease of access and very low threshold of capital and skill needed to enter and engage in most of these activities especially those relating to nontimber forest products [50] such as fuelwood gathering and marketing [48].

In addition, it was shown that several other intrinsic and extrinsic factors do influence choice of species to be incorporated and sustained in agroforestry systems. In buttressing this, Erakhrumen [11] and Erakhrumen [18] evaluated the influence of wood energy and specific gravity (SG), two intrinsic properties of fuelwood, on its incorporation and sustenance in a specific type of agroforestry system, that is, scattered trees in croplands that is predominant in the study area. It was noted, based on the prioritisation done by respondents in the study area, that both properties had influence on the choice of wood species for agroforestry in the study area.

Wood energy, in the form of net calorific value (NCV), for twelve species that top the priority ranking of the respondents in the study area was noted to have values that ranged between 14.65 and $21.68 \mathrm{MJ} \mathrm{kg}^{-1}$, and it was shown that Pearson moment correlation value $\left(r^{2}\right)$ was as high as $0.874(P<0.05)$ between NCV and cumulative ranking values (CRV) in the study area [11]. Likewise, it was also shown that SG of the same twelve species ranged between 0.42 and 0.85 with an $r^{2}$ value $>0.80(P<0.05)$ between SG and CRV in the same study area [18].

Furthermore, Erakhrumen [4] investigated the extent to which NCV and SG, collectively and individually, influenced the choice of fuelwood for agroforestry using linear regression models. It was found out that estimating CRV using both NCV and SG as predictors produced a model with a coefficient of determination $\left(R^{2}\right)$ of $77.1 \%$ with a significant analyses of variance (ANOVA) result for the model. Estimating CRV using NCV alone as a predictor produced a model with an $R^{2}$ of $67.7 \%$ with ANOVA showing significant relationship between CRV and NCV, while that for using SG as a predictor produced a model with an $R^{2}$ of $75.7 \%$ also with a significant relationship between CRV and SG. Similarly, it was also shown that NCV and SG were positively correlated as also earlier shown by Erakhrumen [52] for the same woody species in the study area.
Nevertheless, it is important to note that many other factors that were not part of the studies reported earlier can also influence NCV and SG. Among these factors, as also highlighted in the papers $[4,11,18]$ are presence of other combustible material in wood, influence of various parts of species and position of wood along and across the bole, variation of the components properties of species, age of woody species, species' genetic character and biochemical composition, difference in applied silvicultural techniques and/or management regimes during growth, source of provenances, geographical region, seed source, and types and nutrient status of soils on which the species are grown, among others.

As stated previously, the studies highlighted earlier were carried out to identify some factors that are responsible for and/or influence the incorporation into and sustenance of components, such as wood, in different systems of agroforestry practices. There are many other factors such as its use for soil fertility improvement and maintenance through nutrient cycling, erosion control, production of wood for construction purposes, fodder supply, fruits production, control of livestock, living fences, stakes, ornamental value, shades, and windbreaks, just to mention a few.

On the other hand, as important as fuelwood is in many rural communities, there are other traditional uses to which all parts of these woody species can also be put such as for culinary purposes in the form of food, juices, spices, condiments, oil, medicinal uses, chew stick, ethnoveterinary medicine, as browse species for animals, habitat for some beneficial insects, among others $[6,10]$ thereby making inclusion of many of the woody species on the list of preferred fuelwood species a good pointer to both the importance of wood as domestic energy source in many of the rural areas and the declining state, in terms of quantity of woody resources for this purpose.

Therefore, in order to develop and implement sustainable agroforestry policies and/or in the establishment of agroforestry plots, as also stated earlier, there will be the need to be acquainted with information relating to locally devised and acceptable basis for the production of renewable natural resources, particularly those relating to native intelligence, indigenous/traditional knowledge, and/or users' perspectives of its components. In addition, the information may be necessary for, lead to, or aid future studies for the development of urban woodlots as briefly highlighted in a study that evaluated the potentials of an avenue tree as fuelwood by Ogunsanwo et al. [53].

\section{Conclusion and Recommendations}

Wood usage as fuel has been shown not only to be important in many parts of the world but also to be increasing in volume and intensities of use, and this is one of the reasons why series of studies had been and are still being carried out with outputs that are aimed toward sustainable production and use of this renewable natural resources for energy generation. This is the main thrust of this paper that has been aimed at contributing to increasing the awareness of all stakeholders concerning increased global use of wood fuel and how 
renewable natural resources production methods, such as agroforestry, can be improved for sustainable production of wood for different purposes.

The factors highlighted in this paper are in no way exhaustive because there are many other factors, as earlier indicated, that are location/regionally dependent. Wood fuel use in developing countries is not merely for cooking and heating as there are other socioeconomic and cultural determinants influencing its application for these purposes. For example, in many parts of Africa, during cooking and heating, some harvested farm produce, bush meat, and other types of animal parts that require processing and preservation through smoking and drying can be simultaneously smoked or dried.

Apart from this and other factors, it is also important to note that the technical level and efficiency of wood fuel energy conversion system in use in this part of the world is generally very low and mostly out of date with many improvement possibilities available. Improvement on these technical and efficiency levels, in line with local realities and acceptance, are expected to aid in reducing fuelwood and charcoal consumption through efficient conversion methods and devices that put available wood energy to more frugal use as its usage is presently far from being outmoded in many parts of the world.

\section{References}

[1] A. A. Erakhrumen, "Overview of various biomass energy conversion routes," American-Eurasian Journal of Agricultural \& Environmental Sciences, vol. 2, no. 6, pp. 662-671, 2007.

[2] C. May-Tobin, "Wood for fuel," in The Root of the Problem: What's Driving Tropical Deforestation Today? p. 11, The Union of Concerned Scientist, 2011.

[3] A. A. Erakhrumen, "Wood biomass as a major source of energy in sub-sahara African region: implications for sustained research and education in agroforestry technologies," in Research for Development in Forestry, Forest Products and Natural Resources Management. Proceedings of the 1st Biannual Conference of the Forests and Forest Products Society of Nigeria, J. C. Onyekwelu, V. A. J. Adekunle, and D. O. Oke, Eds., pp. 205-211, Federal University of Technology, Akure, Nigeria, April 2008.

[4] A. A. Erakhrumen, "Estimating the extent of influence of two intrinsic fuelwood properties on acceptance/retention of some woody species in agroforestry practices in Southwest Nigeria," Drvna Industrija, vol. 60, no. 4, pp. 209-218, 2009.

[5] A. A. Erakhrumen, "Implications of global economic recession/volatility in petroleum products' price, demand, and supply on fuelwood consumption and mangrove forests' survival in the niger-delta region," in Research for Development in Forestry, Forest Products and Natural Resources Management. Proceedings of the 1st Biannual Conference of the Forests and Forest Products Society of Nigeria, L. Popoola, F. O. Idumah, V. A. J. Adekunle and I. O. Azeez, and I. O. Azeez, Eds., pp. 136147, Federal University of Technology, Benin-City, Nigeria, October 2010.

[6] A. A. Erakhrumen, O. Y. Ogunsanwo, and O. I. Ajewole, "Assessment of some other traditional uses of accepted agroforestry fuelwood species in akinyele and ido local government areas, Oyo State, Nigeria," International Journal of Social Forestry, vol. 3, no. 1, pp. 47-65, 2010.

[7] A. B. Temu, "African forestry and challenges of sustainable livelihood," in Forestry and Challenges of Sustainable Livelihood, Proceedings of the 28th Annual Conference of the Forestry Association of Nigeria, J. E. Abu, P. I. Oni, and L. Popoola, Eds., pp. 1-10, Akure, Ondo State, Nigeria, 2002.

[8] FAO, "State of the World's Forests," Food and Agriculture Organization of the United Nations, Rome, Italy.

[9] FAO, "Criteria and indicators for sustainable woodfuels," in Case Studies from Brazil, Guyana, Nepal, Philippines and Tanzania, S. Rose, E. Remedio, and M. A. Trossero, Eds., p. 274, FAO, 2009.

[10] A. A. Erakhrumen, "Some other uses of accepted agroforestry fuelwood species based on traditional knowledge in selected rural communities of Oyo State, Southwest, Nigeria," in Traditional Forest-Related Knowledge and Sustainable Forest Management in Africa, Proceedings of an International Conference held in Accra-Ghana, J. A. Parrotta and A. Oteng-Yeboah, Eds., vol. 23 of IUFRO World Series, pp. 85-92, 2009.

[11] A. A. Erakhrumen, "Energy value as a factor of agroforestry wood species selectivity in Akinyele and Ido local government areas of Oyo State, Nigeria," Biomass and Bioenergy, vol. 33, no. 10, pp. 1428-1434, 2009.

[12] G. Leach, “The energy transition," Energy Policy, vol. 20, no. 2, pp. 117-123, 1992.

[13] T. B. Johansson, H. Kelly, A. K. N. Reddy, and R. H. Williams, "A renewable intensive global energy scenario," in Renewable Energy: Sources for Fuels and Electricity, T. B. Johansson, H. Kelly, A. K. N. Reddy, and R. H. Williams, Eds., pp. 1071-1140, Island, Washington, DC, USA, 1993.

[14] CFA, Commonwealth Forests 2010: An Overview of the Forests and Forestry Sectors of the Countries of the Commonwealth, Commonwealth Forestry Association, Shropshire, UK, 2010.

[15] G. Hiemstra-van der Horst and A. J. Hovorka, "Fuelwood: the "other" renewable energy source for Africa?" Biomass and Bioenergy, vol. 33, no. 11, pp. 1605-1616, 2009.

[16] A. Egeru, P. Okello, M. G. J. Majaliwa, P. Mukwaya, and P. Isubikalu, "The effect of land use/cover change on biomass stock in dryland areas of Eastern Uganda. A case study of olio sub-county in soroti district," Journal of Applied Sciences \& Environmental Management, vol. 14, pp. 101-106, 2010.

[17] O. Hofstad, G. Kohlin, and J. Namaalwa, "How can emissions from woodfuel be reduced?" in Realising REDD+: National Strategy and Policy Options, A. Angelsen, M. Brockhaus, M. Kanninen, E. Sills, W. D. Sunderlin, and S. Wertz-Kanounnikoff, Eds., pp. 237-249, Center for International Forestry Research, Bogor, Indonesia, 2009.

[18] A. A. Erakhrumen, "Influence of specific gravity on wood species selection for agroforestry in some local government Areas of Oyo State, Nigeria," African Journal of Agricultural Research, vol. 3, no. 2, pp. 134-139, 2008.

[19] A. Koopmans, Wood Energy Development in Asia: Assessment of Critical Issues, Constraints and Prospects, Regional Expert Consultation on Data Assessment and Analysis for Wood Energy Planning, Chiang Mai, Thailand, 1993.

[20] FAO, "Unified Bioenergy Terminology (UBET)," Forestry Department, Wood Energy Programme, Food and Agriculture Organization of the United Nations, Rome, Italy, 2004, ftp:// ftp.fao.org/docrep/fao/007/j4504e/j4504e00.pdf.

[21] T. Gumartini, "Biomass energy in the Asia-Pacific region: current status, trends and future setting," Asia-Pacific Forestry Sector Outlook Study II, Food and Agriculture Organization 
of the United Nations Regional Office for Asia and the Pacific, 2009, Working Paper Series, Working Paper No. APFSOS II/WP/2009/26.

[22] J. Broadhead, J. Bahdon, and A. Whiteman, "Past trends and future prospects for the utilization of wood energy," Annexes 1 and 2. Global Forest Products Outlook Study Working Paper No. GFPOS/WP/05, Food and Agriculture of the United Nations, Rome, Italy, 2001.

[23] ITTO, Tropical Forest Update, ITTO, Yokohama, Japan, 2005.

[24] FAO, "The role of wood energy in Europe and OECD," Working Paper FOPW/97/1, Forestry Department, Food and Agriculture Organization of the United Nations, Rome, Italy, 1997.

[25] G. A. Leach, "Residential energy in the Third World," Annual Review of Energy, pp. 47-65, 1988.

[26] UN, Standard Country or Area Codes for Statistical Use: standard country or area codes and geographical regions for statistical use, United Nations Statistics Division, 2010, http:// unstats.un.org/unsd/methods/m49/m49.htm.

[27] ECA, “Transforming Africa's economies," Economic Report on Africa 2000, Economic Commission for Africa (ECA), Addis Ababa, Ethiopia, 2001.

[28] S. Canagarajah, "Poverty and welfare in nigeria," Survey Report. Federal Office of Statistics and the National Planning Commission of the Federal Republic of Nigeria and the World Bank, American Writing Corporation, Washington, DC, USA, 1998.

[29] The Independent, "Birth rates 'must be curbed to win war on global poverty”, 2007, http://www.independent.co.uk/news/ world/politics/birth-rates-must-be-curbed-to-win-war-onglobal-poverty-434387.html.

[30] IEA, World Energy Outlook 2002 Edition - Energy and Poverty Chapter, International Energy Agency, Paris, France, 2002.

[31] World Bank, Poverty \& Inequality Analysis, 2011, http://web .worldbank.org/WBSITE/EXTERNAL/TOPICS/EXTPOVERTY/0,,contentMDK:22569747 pagePK:148956 piPK: 216618 theSitePK:336992,00.html.

[32] A. A. Erakhrumen, "State of forestry research and education in Nigeria and sub-saharan Africa: implications for sustained capacity building and renewable natural resources development," Journal of Sustainable Development in Africa, vol. 9, no. 4, pp. 133-151, 2007.

[33] FAO, Socio-Economic Aspects of Bioenergy: A Focus on Employment, E. M. Remedio of the Food and Agriculture Organization of the United Nations, Rome, Italy, 2001.

[34] FAO, "Technical and economic aspects of using woodfuel in rural industries," in Proceeding of the Electronic Conference, Food and Agriculture Organization of the United Nations, Rome, Italy, 1987.

[35] J. Goldemberg, Ed., World Energy Assessment: Energy and the Challenge of Sustainability, UN Development Programme, New York, NY, USA, 2000.

[36] R. Anil Cabraal, D. F. Barnes, and S. G. Agarwal, "Productive uses of energy for rural development," Annual Review of Environment and Resources, vol. 30, pp. 117-144, 2005.

[37] ICRAF, "International council for agroforestry," Plant Research and Agroforestry, ICRAF, Nairobi, Kenya, 1983.

[38] D. O. Ladipo, A. A. Adebisi, and H. G. Adewusi, "Domestic energy and conservation needs for indigenous forest species in Nigeria," in Forestry and Challenges of Sustainable Livelihood, Proceedings of the 28th Annual Conference of the Forestry Association of Nigeria, J. E. Abu, P. I. Oni, and L. Popoola, Eds., pp. 22-29, Akure, Nigeria, 2002.
[39] P. K. R. Nair, "State of art of agroforestry systems," in Agroforestry: Principles and Practices, P. G. Jarvis, Ed., pp. 5-29, Elsevier, Amsterdam, The Netherlands, 1991.

[40] ICRAF, "Annual Report (1991)," International Centre for Research in Agroforestry, 1991.

[41] A. S. I. Birma, "The practice of agroforestry in threatened arid and semi arid areas as land use options for increased food and fuelwood production on sustainable basis," in Conservation of Nigeria's Natural Resources and the Threatened Environment, Proceedings of the 26th Annual Conference of the Forestry Association of Nigeria, P. C. Obiaga, J. E. Abu, L. Popoola, and G. Ujor, Eds., pp. 76-84, Maiduguri, Nigeria, 1999.

[42] S. Y. Anane and R. Twumasi-Ankrah, "Woodlots-profitable venture for Ghana's smallholders farmers," Agroforestry Today, vol. 10, pp. 19-21, 1998.

[43] C. K. Ssekabembe, College Agroforestry, vol. 14, Makerere University Press, 2003.

[44] J. O. Adegbehin, "Procurement of fuelwood using fastgrowing tree species," in Our Forest, Environment and Heritage: Challenges for our People, Proceedings of the 22nd Annual Conference of the Forestry Association of Nigeria, F. A. Akinsanmi, Ed., Kano, Nigeria, 1992.

[45] C. Mahlako, "Farmer to farmer: rural people's role in generating and disseminating agroforestry technology and some participatory approaches to agroforestry extension," AERDD, University of Reading Rural Extension Bulletin, vol. 2, pp. 1822, 1993.

[46] P. R. O. Kio, "Community forestry for sustainable forest development," in Forests, People and Environment, Proceedings of a National Workshop Organised by FANCONSULT and Edo State Chapter of Forestry Association of Nigeria, L. Popoola, Ed., Benin-City, Nigeria, 2002.

[47] A. A. Erakhrumen and O. Y. Ogunsanwo, "Women as major stakeholders in sustainable agroforestry fuelwood development," in Sustainable Forest Management in Nigeria: Lessons and Prospects, Proceedings of the 30th Annual Conference of the Forestry Association of Nigeria, L. Popoola, P. Mfon, and P. I. Oni, Eds., pp. 631-639, Kaduna, Nigeria, 2005.

[48] O. Y. Ogunsanwo and A. A. Erakhrumen, "Gender influence on firewood sourcing for income generation in selected rural communities of Oyo State, Nigeria," Journal of Tropical Forest Resources, vol. 22, no. 1, pp. 76-83, 2006.

[49] D. U. U. Okali and F. O. Amubode, "Resource conservation in Oboto, Nigeria," in Towards Common Ground: Gender and Natural Resource Management in Africa, A. Sigot, L. A. Thrupp, and J. Green, Eds., pp. 27-47, Kenya and World Resources Institute, Washington DC, USA, 1995.

[50] O. I. Oladele, "Gender analysis of forest product exploitation among enclave dwellers in omo forest reserve, Ogun State, Nigeria," Journal of Tropical Forest Resources, vol. 17, no. 1, pp. 127-132, 2001.

[51] UNICEF, "Millennium Development Goals: Eradicate Extreme Poverty and Hunger," http://www.unicef.org/mdg/poverty.html.

[52] A. A. Erakhrumen, "Predicting net calorific value from specific gravity of fuelwood species from agroforestry plots in Southwestern Nigeria," The Nigeria Journal of Forestry, vol. 36, no. 1, pp. 61-70, 2006.

[53] O. Y. Ogunsanwo, A. A. Erakhrumen, and A. Otorokpo, "Energy value of selected parts of Peltophorum pterocarpum (D.C.) Backer ex K. Heyne: an avenue tree in the University of Ibadan Campus, Ibadan, Nigeria," OBECHE, vol. 26, no. 1, pp. 78-85, 2008. 

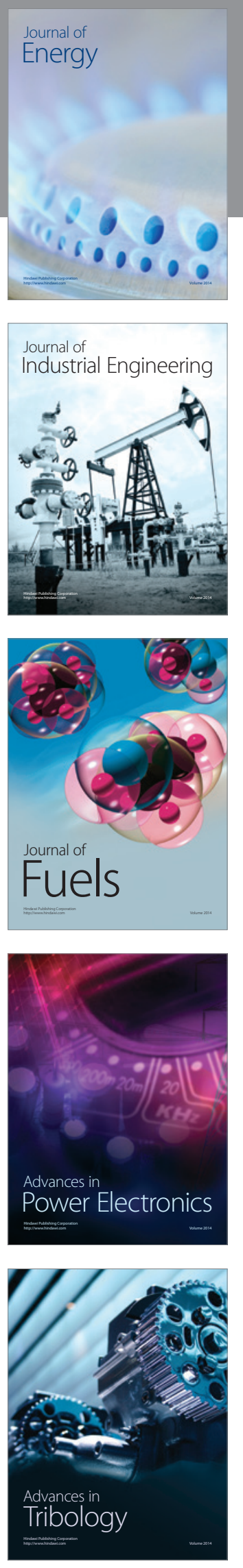
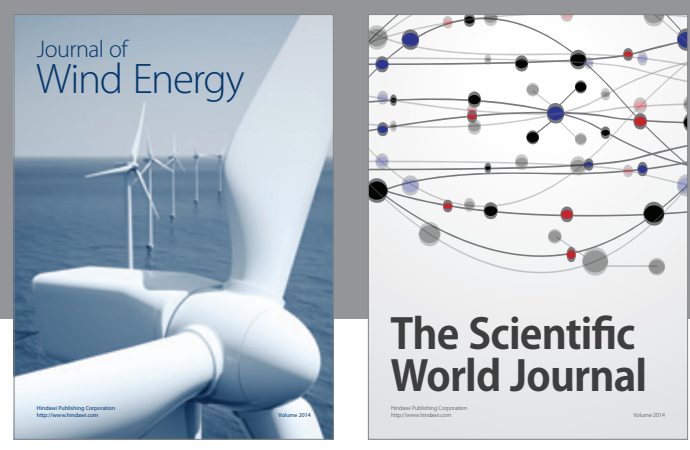

The Scientific World Journal

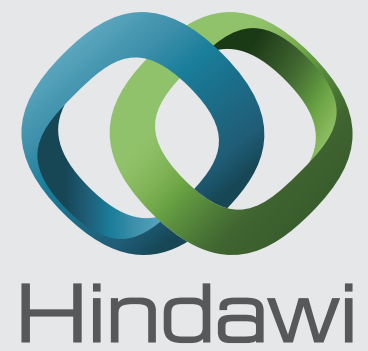

Submit your manuscripts at http://www.hindawi.com
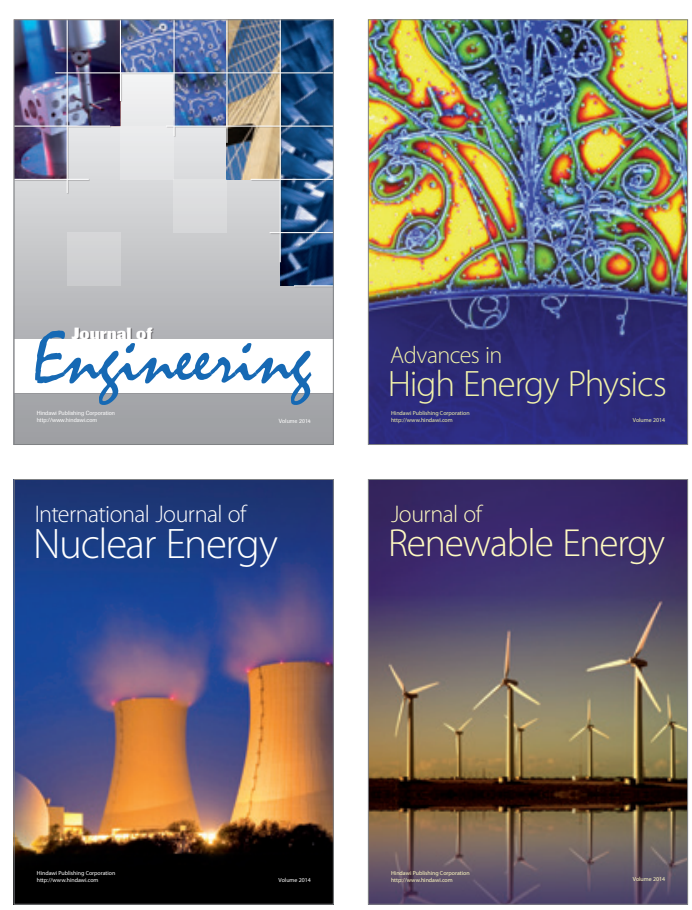

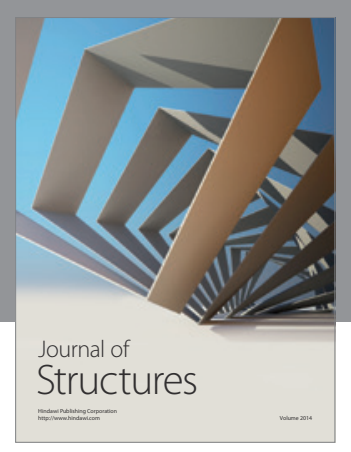

Rotating
Mechinery
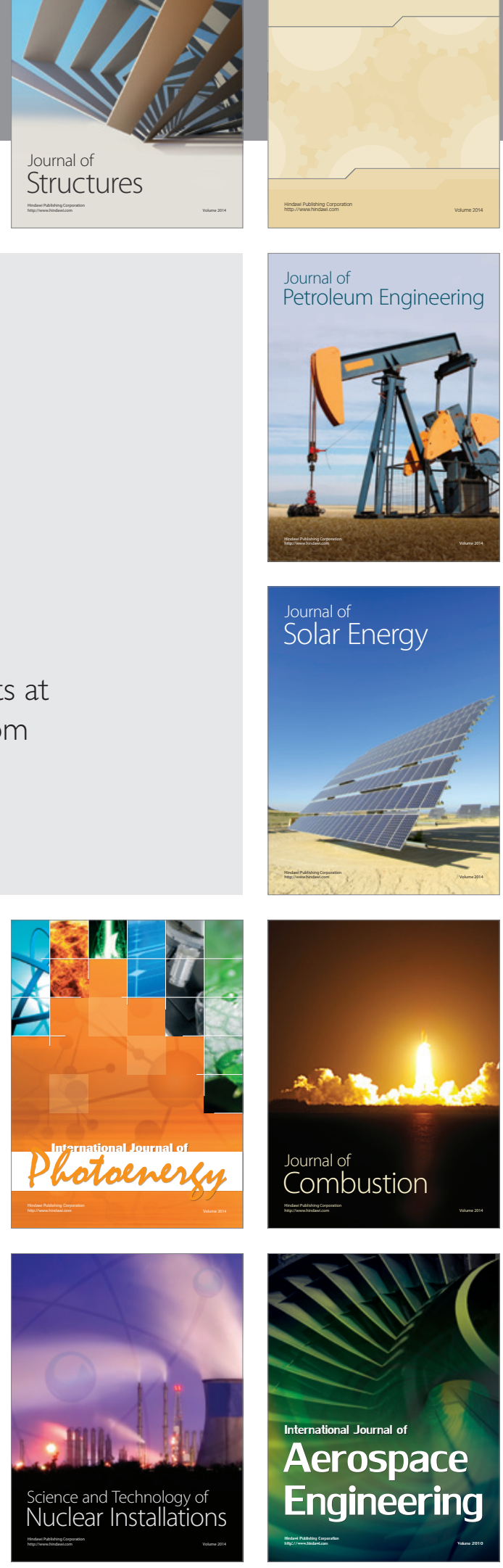